9-1-2005

\title{
Homing Behavior of Musk Turtles in a Virginia Lake
}

Randolph Chambers

rmcham@wm.edu

Follow this and additional works at: https://scholarworks.wm.edu/aspubs

Part of the Biology Commons

\section{Recommended Citation}

Chambers, Randolph, Homing Behavior of Musk Turtles in a Virginia Lake (2005). Southeastern Naturalist, $4(3), 527-532$.

10.1656/1528-7092(2005)004[0527:HBOMTI]2.0.CO;2

This Article is brought to you for free and open access by the Arts and Sciences at W\&M ScholarWorks. It has been accepted for inclusion in Arts \& Sciences Articles by an authorized administrator of W\&M ScholarWorks. For more information, please contact scholarworks@wm.edu. 


\title{
BioOne COMPLETE
}

\section{Homing Behavior of Musk Turtles in a Virginia Lake}

\author{
Authors: Christina M. Smar, and Randolph M. Chambers \\ Source: Southeastern Naturalist, 4(3) : 527-532 \\ Published By: Eagle Hill Institute \\ URL: https://doi.org/10.1656/1528-7092(2005)004[0527:HBOMTI] \\ 2.0.CO;2
}

BioOne Complete (complete.BioOne.org) is a full-text database of 200 subscribed and open-access titles in the biological, ecological, and environmental sciences published by nonprofit societies, associations, museums, institutions, and presses.

Your use of this PDF, the BioOne Complete website, and all posted and associated content indicates your acceptance of BioOne's Terms of Use, available at www.bioone.org/terms-of-use.

Usage of BioOne Complete content is strictly limited to personal, educational, and non-commercial use. Commercial inquiries or rights and permissions requests should be directed to the individual publisher as copyright holder.

BioOne sees sustainable scholarly publishing as an inherently collaborative enterprise connecting authors, nonprofit publishers, academic institutions, research libraries, and research funders in the common goal of maximizing access to critical research. 


\title{
Homing Behavior of Musk Turtles in a Virginia Lake
}

\author{
Christina M. Smar ${ }^{1}$ and Randolph M. Chambers ${ }^{1, *}$
}

\begin{abstract}
For nine weeks during the summer of 2002, a mark and recapture technique was used to study homing behavior of Musk Turtles (Sternotherus odoratus) living in Lake Matoaka, VA. During the first three weeks of the study, 119 turtles ( 83 male, 36 female) were captured using unbaited crabpots, then marked and displaced from the site of capture. Turtles were displaced $100 \mathrm{~m}$ across open water $4 \mathrm{~m}$ deep, $520 \mathrm{~m}$ along the same shore, or $550 \mathrm{~m}$ across open water. For the last six weeks of the study, 110 turtles (65 males, 45 females) were captured and released with no displacement. Overall, 39\% (49/126) of males and 21\% (15/71) of females in this study were captured more than once. Seventy-five of 118 recaptures $(64 \%)$ were at the site of most recent release (sedentary behavior) and 11 recaptures (9\%) were at neither the original nor most recent site of capture (non-homing behavior). Thirtyfour of 118 recaptures of displaced turtles (29\%) occurred at the site of original capture, and 31 (91\%) of these movements were made by males, a significant difference in homing behavior between males and females during the time of the study. Neither distance nor open water significantly impeded turtle homing.
\end{abstract}

\section{Introduction}

Many species of freshwater turtles demonstrate fidelity to both their home range and nest site (Cagle 1944). This phenomenon has been documented by the chronic recapture of individual turtles at the same locations, sometimes with as much as a year between captures (Ernst 1970). Due to their mobility and capacity to migrate large distances through water and over land (Bowne 2002), patterns of turtle homing movements following geographic displacement have also been examined. For example, some species of freshwater turtles can successfully orient to water when placed on land (Emlen 1968, Gould 1959, Lebboroni and Chelazzi 2000, Yeomans 1995), and others exhibit homing behavior when displaced in water away from a site of original capture (Ernst 1970, Lebboroni and Chelazzi 2000, Williams 1952). Many visual and olfactory cues have been suggested as the putative mechanism underlying turtle homing behavior, but the strength of these cues tends to diminish with displacement distance (Emlen 1968), and a difference in homing behavior between male and female turtles has rarely been observed (Ernst 1970).

The Common Musk Turtle, Sternotherus odoratus Latreille, is a species of aquatic turtle commonly found throughout eastern North America in both lacustrine and riverine habitats. Musk Turtles are known to exhibit homing behavior (Ernst 1986, Mahmoud 1969), and in Virginia lakes, are most frequently recaptured at sites of original capture (Holinka et al. 2003, Mitchell 1988). Holinka et al. (2003) documented that some male and female

${ }^{1}$ Biology Department, Keck Lab, Wake Drive, College of William and Mary, Williamsburg, VA 23187. "Corresponding author - rmcham@wm.edu. 
Musk Turtles traveled an average of $320 \mathrm{~m}$ between capture sites located along the same shoreline. Because few turtles were recorded moving much shorter distances across open water, they hypothesized that the physical environment between trapping locations might impede turtle movements.

Our objective was to document the homing behavior of Musk Turtles in a small Virginia lake. We tested the ability of Musk Turtles to return to points of original capture following displacement within the lake (Gould 1959). By displacing turtles and monitoring their subsequent movements, we tested whether distance or open water would impede homing success. Because male turtles have been observed to travel farther than females (Mahmoud 1969), and may have different average activity ranges (Ford and Moll 2004), we also wanted to determine whether homing behaviors were similar for male and female Musk Turtles.

\section{Methods}

From May to August of 2002, we monitored the movements of Musk Turtles among three sites in Lake Matoaka, a 280-year old, 16 ha impoundment on the Atlantic coastal plain in Williamsburg, VA (Fig. 1). Sites A and B were separated by a long distance $(550 \mathrm{~m})$ along the shoreline, sites $A$ and $C$ were separated by a short distance $(100 \mathrm{~m})$ across open water (depth $4 \mathrm{~m})$, and sites B and $\mathrm{C}$ were separated by a long distance across open water (520 m, depth $4 \mathrm{~m}$ ).

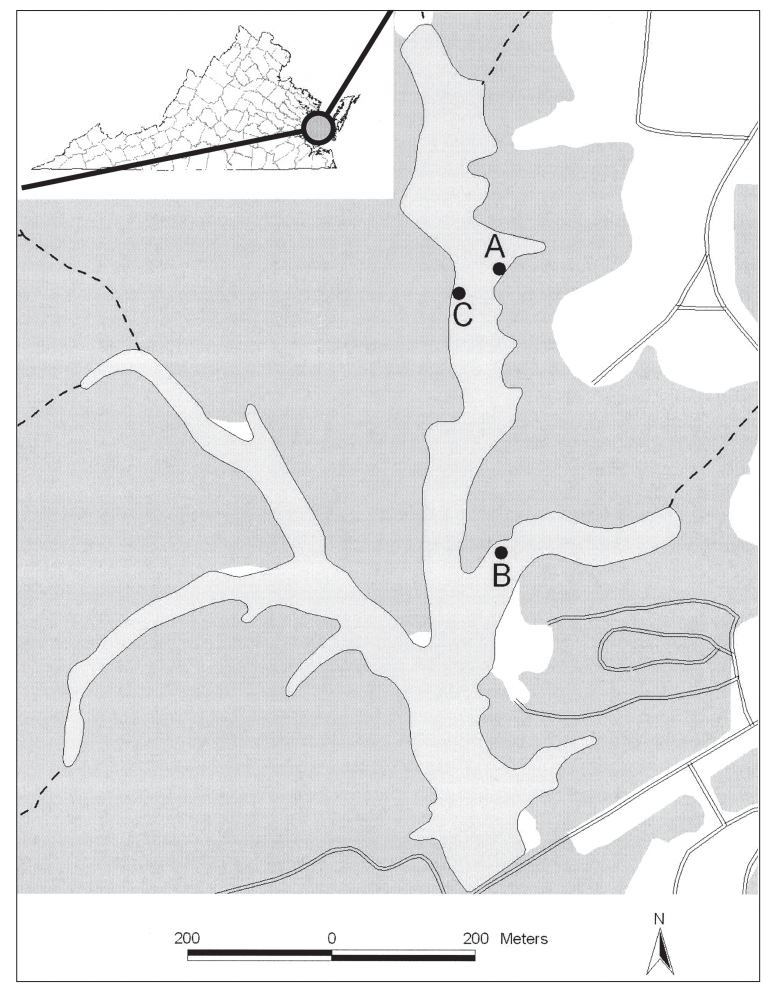

Figure 1. Site map of Lake Matoaka on the College of William and Mary campus in Williamsburg, VA (76.72W, $37.27 \mathrm{~N})$. The separation between pairs of sampling locations is distinguished by: long shoreline distance (A to B, $550 \mathrm{~m}$ ); open water (A to C, $4 \mathrm{~m}$ depth); both long shoreline distance and open water (B to $\mathrm{C}, 520$ $\mathrm{m}$ and $4 \mathrm{~m}$ depth). 
At each of the three capture sites, three unbaited crabpots $(60 \times 60 \times 53 \mathrm{~cm})$ were partially submerged approximately $50 \mathrm{~cm}$ deep along the lake's shore. Unbaited crabpots trap Musk Turtles safely, and trapping effectiveness is not influenced by prior capture or the presence of turtles of either sex already in the traps (Holinka et al. 2003). All captured turtles were sexed, then marked using a binary code of notches filed into the marginal scutes (Cagle 1939).

For the first 21 days of the study, turtles were displaced from sites of original capture to introduce potential impedances to homing movements (long distance and/or open water). Every other day, newly captured turtles at one location were displaced to one of the other two trapping locations, yielding turtle displacement from locations $\mathrm{A}$ to $\mathrm{B}, \mathrm{B}$ to $\mathrm{C}$, and $\mathrm{C}$ to $\mathrm{A}$ (Fig. 1). On alternate days, newly captured turtles were displaced in the opposite release pattern (i.e., B to A, C to B, and A to C).

To determine the frequency of recapture for non-displaced turtles, every day for the final six weeks captured turtles were simply released at the point of capture without displacement. The period also provided sufficient time for recapture of turtles displaced during the first three weeks of the study. Throughout the entire nine weeks, we recorded sedentary recaptures, homing recaptures (displaced turtles recaptured at the site of original capture), and non-homing recaptures (turtles caught at neither the most recent site of release nor the site of original capture). We used a t-test to compare the average time elapsed for sedentary and non-sedentary recaptures, and chi-square tests to compare the number and sex ratios of homing and non-homing recaptures and the number of recaptures among impedance classes.

\section{Results}

A total of 126 male and 71 female Musk Turtles were captured, yielding a sex ratio of 1.8:1 (Table 1). Of these 197 turtles, $133(68 \%)$ were captured only once, with a sex ratio of $1.4: 1$. The remaining 49 male and 15 female turtles were recaptured on average $1.7 \pm 1.2$ S.D. times. During the first three weeks, 83 male and 36 female turtles were displaced from their sites of original capture. For recaptures throughout the entire study (118), 64\% were sedentary. Sedentary recaptures occurred with a sex ratio of $1.8: 1$, equal to the sex ratio of all turtles in the study (Table 1).

Table 1. Summary of turtle captures and recaptures in Lake Matoaka, VA.

\begin{tabular}{lccc} 
& Males & Females & Ratio \\
\hline Turtles in study & 126 & 71 & $1.8: 1$ \\
Single captures & 77 & 56 & $1.4: 1$ \\
Turtles captured multiple times & 49 & 15 & $3.3: 1$ \\
Average number of recaptures/turtle & 1.8 & 2.0 & $1.8: 1$ \\
Sedentary recaptures $^{\mathrm{A}}$ & 48 & 27 & $10.3: 1$ \\
Homing recaptures $^{\mathrm{B}}$ & 31 & 3 & $\infty$ \\
Non-homing recaptures $^{\mathrm{C}}$ & 9 & 0 & \\
${ }^{\mathrm{A}}$ Turtles recaptured at their most recent site of release. & & \\
${ }^{\mathrm{B}}$ Displaced turtles recaptured at their site of original capture. & \\
${ }^{\mathrm{C}}$ Turtles recaptured at other sites, i.e., not most recent site of release or site of original capture.
\end{tabular}


For turtles that were recaptured at locations other than the site of release, significantly more homing (34) than non-homing (9) recaptures were recorded (chi-square goodness-of-fit test: $\chi^{2}=14.5$, d.f. $=1, \mathrm{p}<0.05$ ). Ninetyone percent ( 31 of 34 ) of the homing movements were by displaced males, with only $9 \%$ ( 3 of 34 ) by females (Table 1). The male:female sex ratio of observed homing movements (10.3:1) was significantly higher than the sex ratio of all displaced turtles (2.3:1) (chi-square test for independence: $\chi^{2}=$ 7.3 , d.f. $=1, \mathrm{p}<0.05)$, demonstrating that homing behavior was malebiased. Further, 100\% (9 of 9) of the observed non-homing movements to alternate trapping locations were made by males. Of these nine non-homing movements, five occurred after displacement, and four occurred when a turtle had not been displaced.

The average length of time between movements to another location was $10.8 \pm 9.2$ S.D. days. Males and females exhibited similar movement times $(10.8 \pm 9.5$ and $11.7 \pm 4.5$ days, respectively). One male turtle returned to its site of original capture across open water and $520 \mathrm{~m}$ shoreline distance in less than one day, having been captured, displaced, and recaptured on consecutive days. The length of time between non-sedentary recaptures ranged from 1 to 37 days. For sedentary recaptures, the average length of time between captures was $8.5 \pm 8.2$ S.D. days. The average length of time between sedentary and non-sedentary recaptures was not significantly different $(\mathrm{t}=1.38, \mathrm{p}>0.05)$, i.e., the timing between recaptures was not influenced by displacement from site of original capture. Further, none of the experimental turtle displacements appeared great enough to impede turtle movements (Table 2). For the 34 documented homing movements to sites of original capture (34/109 recaptures), return rates between treatments were not significantly different (chi-square test for independence, $\chi^{2}=0.70$, d.f. $=2, \mathrm{p}>0.05)$. Similarly, the nine non-homing movements by male turtles (9/109 recaptures) were equally distributed among impedance classes (chi-square test for independence, $\chi^{2}=0.18$, d.f. $=2, \mathrm{p}>0.05$ ) (Table 2).

\section{Discussion}

Musk Turtles appear to exhibit strong fidelity to sites of original capture. Based on recapture data, a majority of turtles remained in close proximity to individual traps. Holinka et al. (2003) documented multiple recaptures (up to 23 times) of Musk Turtles at the same trapping location. In that study, the average recapture distance of 77 turtles in Lake Matoaka was $320 \mathrm{~m}$, with the longest distance between captures of 1175 m. Similarly, Mitchell (1988)

Table 2. Summary of turtle movements after displacement from site of original capture.

\begin{tabular}{lccc} 
Impedance class & $\begin{array}{c}\text { Number of } \\
\text { displacements }\end{array}$ & $\begin{array}{c}\text { Homing } \\
\text { recaptures }\end{array}$ & $\begin{array}{c}\text { Non-homing } \\
\text { recaptures }^{\mathrm{A}}\end{array}$ \\
\hline Distance & 67 & 13 & 3 \\
Open water & 48 & 11 & 3 \\
Distance and open water & 62 & 10 & 3 \\
A Includes movements by displaced (5) and non-displaced (4) turtles. & \\
\hline
\end{tabular}


recaptured turtles at sites of original capture after displacement. Further evidence of site fidelity is provided by the apparent homing behavior of turtles displaced from sites of original capture.

Our data suggest that displaced males are more likely to return to home sites than females (Table 1). Although a study by Ernst (1970) found that the return time for female painted turtles from displaced distances (up to $3.2 \mathrm{~km}$ ) was much longer than for males, in the present study the time to recapture for the three females exhibiting homing behavior was similar to males. The speed with which Musk Turtles return to home sites, however, cannot be directly determined from our data. In an earlier study, Williams (1952) suggested that displaced Musk Turtles may wander along shallow pond margins and return to their recognized home sites accidentally. The broad range in our homing recapture times could indicate that homing turtles exhibit variable return rates, or that turtles home rapidly, but that time to recapture once at the home site is variable. We found no significant difference in the average time between sedentary and homing recaptures, so displacement itself did not influence the time to recapture.

More males than females were recaptured in this study, but the average number of recaptures per turtle was similar by sex (Table 1). What differed was the location of those recaptures: far more males than females were recaptured at alternate trapping locations from where they had last been released. More extensive movements and larger home range sizes of male turtles may increase mating opportunities (Morreale et al. 1984, Parker 1984) and decrease inbreeding with related females (Alcock 1998). In contrast to a more sedentary strategy of females (Morreale et al. 1984), male activities may also be a result of competition for food, habitat, or females.

To sum, neither distance nor open water was an impedance to the movement of turtles in Lake Matoaka. Especially for male Musk Turtles in this study, home site fidelity was demonstrated both by homing after displacement and by repeated recapture at the home site. Because male turtles tended to exhibit both homing and non-homing movements, their home ranges may be larger than those of females. The more frequent and extensive movement of male turtles is consistent with the observed male-biased sex ratio in the lake and would increase the frequency of encounters with potential female mates or other limiting resources.

\section{Acknowledgments}

Thanks to Bonnie Ludlow, Tim Wygant, and Alison Holinka for field assistance, and to Timothy Russell for GPS help. Earlier versions of the manuscript. were improved by Dan Cristol and two anonymous reviewers. This work was funded by a Charles Center summer research grant, and is publication \#005 of the W.M. Keck Environmental Field Laboratory.

\section{Literature Cited}

Alcock, J. 1998. Animal Behavior: An Evolutionary Approach. Sinauer Associates, Inc, Sunderland, MA. 625 pp. 
Bowne, D.R. 2002. Linking individual behavior to population processes at the landscape level. Ph.D. Dissertation, University of Virginia, Charlottesville, VA. 142 pp.

Cagle, F.R. 1939. A system of marking turtles for future identification. Copeia 1939:170-173.

Cagle, F.R. 1944. Home range, homing behavior, and migration in turtles. Museum of Zoology, University of Michigan, Ann Arbor, MI, Miscellaneous Publication 61:1-34.

Emlen, S.T. 1968. Homing ability and orientation in the Painted Turtle Chrysemys picta marginata. Behaviour 33:58-76.

Ernst, C.H. 1970. Homing ability in the Painted Turtle, Chrysemys picta (Schneider). Herpetologica 26:399-403.

Ernst, C.H. 1986. Ecology of the turtle, Sternotherus odoratus, in southeastern Pennsylvania. Journal of Herpetology 20:341-352.

Ford, D.K., and D. Moll. 2004. Sexual and seasonal variation in foraging patterns in the Stinkpot, Sternotherus odoratus, in southwestern Missouri. Journal of Herpetology 38:296-301.

Gould, E. 1959. Studies on the orientation of turtles. Copeia 1959:174-176.

Holinka, A.M., R. Dave, and R.M. Chambers. 2003. Population ecology of Stinkpot Turtles (Sternotherus odoratus) in a lake on the mid-Atlantic coastal plain. Chelonian Conservation and Biology 4:721-725.

Lebboroni, M., and G. Chelazzi. 2000. Waterward orientation and homing after experimental displacement in the European Pond Turtle, Emys orbicularis. Ethology, Ecology, and Evolution 12:83-88.

Mahmoud, I.Y. 1969. Comparative ecology of the kinosternid turtles of Oklahoma. Southwestern Naturalist 14:31-66.

Mitchell, J.C. 1988. Population ecology and life histories of the freshwater turtles Chrysemys picta and Sternotherus odoratus in an urban lake. Herpetological Monographs 2:40-61.

Morreale, S.J., J.W. Gibbons, and J.D. Congdon. 1984. Significance of activity and movement in the Yellow-bellied Slider Turtle (Pseudemys scripta). Canadian Journal of Zoology 62:1038-1042.

Parker, W.S. 1984. Immigration and dispersal of Slider Turtles (Pseudemys scripta) in Mississippi farm ponds. American Midland Naturalist 112:280-293.

Williams, J.E. 1952. Homing behavior of the Painted Turtle and Musk Turtle in a lake. Copeia 1952:76-82.

Yeomans, S.R. 1995. Water-finding in adult turtles: Random search or oriented behaviour? Animal Behaviour 49:977-987. 